\title{
PENGARUH OPINI AUDIT, PERGANTIAN AUDITOR, DAN PROFITABILITAS TERHADAP AUDIT REPORT LAG PADA PERUSAHAAN SEKTOR PERDAGANGAN ECERAN YANG TERDAFTAR DI BURSA EFEK INDONESIA PERIODE 2011-2018
}

\author{
Annisa Cahya Ningsih \\ ITB Ahmad Dahlan Jakarta \\ E-mail : sayannisaa@gmail.com \\ Yumniati Agustina \\ ITB Ahmad Dahlan Jakarta \\ E-mail :yumniatiagustina@itb-ad.ac.id
}

\begin{abstract}
ABSTRAK
Penelitian ini bertujuan untuk mengetahui pengaruh opini audit, pergantian auditor, dan profitabilitas terhadap audit report lag pada perusahaan perdagangan eceran yang terdaftar di BEI periode 20112018 dengan menggunakan indikator yang dikeluarkan oleh Otoritas Jasa Keuangan mengenai peraturan tentang laporan tahunan emiten atau perusahaan publik Nomor 29/POJK.04/2016 pasal 7 ayat (1).

Dengan menggunakan metode purposive sampling didapat jumlah sampel sebanyak 6 perusahaan dari 26 perusahaan sebagai populasinya. Teknik analisis data yang digunakan adalah statistik deskriptif dan analisis regresi linear berganda dengan menggunakan uji normalitas, linearitas, Uji Multikolinearitas, Uji Heteroskedastisitas, Uji Autokorelasi.

Hasil penelitian ini menunjukkan bahwa opini audit tidak berpengaruhterhadap audit report lagdengan nilai signifikansi (0,58> 0,05).Pergantian auditor tidak berpengaruh terhadap audit report lagdengan nilai signifikansi $(0,87>0,05)$ dan profitabilitas berpengaruh negatif signifikan secara terhadap audit report lagnilai signifikansi(0,006 $<0,05)$.

Selanjutnya, opini audit, pergantian auditor, dan profitabilitas bersama-saman berpengaruh signifikan terhadap audit report lag, dengan nilai signifikansi $(0,037<0,05)$. Kemampuan opini audit, pergantian auditor dan profitabilitas dalam menerangkan audit report lag pada perusahaan perdagangan eceran sebesar 17,3\%, sedangkan sisanya $82,7 \%$ audit report lag pada perusahaan perdagangan eceran dipengaruhi oleh faktor-faktor lain diluar penelitian.
\end{abstract}

Kata Kunci: Audit Report Lag, Audit Opinion, Auditor Switching, Profitability, Multiple Linear Regression, Retail Trade Company.

\section{PENDAHULUAN}

Setiap perusahaan yang terdaftar di Bursa Efek Indonesia wajib menyampaikan laporan keuangan yang telah diaudit ke pihak eksternal. Laporan keuangan menjadi instrumen paling penting bagi pihak internal seperti manajemen 
dan karyawan atau pihak eksternal perusahaan seperti investor, kreditor, pemerintah dan pemegang saham untuk mengetahui kinerja perusahaan di masa lalu juga sebagai bahan pertimbangan pengambilan keputusan di masa depan. Kriteria laporan keuangan yang baik menurut Halim (2018:63) dipenuhi bila laporan keuangan mempunyai nilai prediktif (predictive value) dan atau nilai balikan (feedback value) dan disajikan tepat pada waktunya. Berdasarkan IAI (2018:13) bahwa informasi keuangan dapat ditingkatkan jika informasi tersebut dapat dibandingkan(comparable),terverifikasi (verifiable), tepat waktu (timely) dan terpaham (understandable). Informasi keuangan juga harus relevan dan representasi tepat.

Otoritas Jasa Keuangan telah mengeluarkan peraturan tentang laporan tahunan emiten atau perusahaan publik Nomor 29/POJK.04/2016. Dalam pasal 7 ayat (1) disebutkan bahwa emiten atau perusahaan publik wajib menyampaikan Laporan Tahunan kepada Otoritas Jasa Keuangan paling lambat pada akhir bulan keempat setelah tahun buku berakhir. Apabila emiten melanggar ketentuan yang telah ditetapkan, pasal 9 ayat (1) telah menetapkan ketentuan sanksi berupa peringatan tertulis, denda yaitu kewajiban untuk membayar sejumlah uang tertentu, pembatasan kegiatan usaha, pembekuan kegiatan usaha, pencabutan izin usaha, pembatalan persetujuan dan pembatalan pendaftaran.

Bursa Efek Indonesia mengganjar denda dan menghentikan sementara (suspensi) perdagangan saham 18 perusahaan tercatat (emiten) karena belum menyampaikan laporan keuangan audit periode 31 Desember 2015 (Sumber

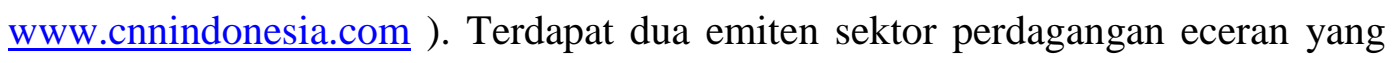
mendapat suspensi yaitu PT Trikomsel Oke Tbk. (TRIO) dan PT. Skybee Tbk. (SKYB) yang memiliki kegiatan utama di bidang perdagangan telepon seluler dan produk penunjang operator seluler yang terdaftar di sub sektor perdagangan eceran. Suspensi juga merujuk pada laporan keuangan tengah tahunan SKYB per 30 Juni 2015, dimana tidak terdapat peningkatan pendapatan dalam laporan keuangan tahunan per 30 Juni 2015 dibanding dengan laporan keuangan per 31 Maret 2015 (Sumber www.kontan.co.id ). Dalam penelitian lainnya audit report lag juga dapat disebut audit delay. Terdapat beberapa faktor yang diduga 
mempengaruhi audit report lag antara lain yaitu, opini audit, pergantian auditor dan profitabilitas.

Perusahaan yang memiliki opini audit unqualified opinion memiliki nilai lebih dimata para investor dibandingkan pendapat lainnya seperti qualified opinion, adverse opinion, disclaimer opinion. Karena perusahaan dengan predikat unqualified opinion dinilai lebih mampu melaporkan laporan keuangannya secara tepat waktu. Hasil penelitian Ariyani dan Budiartha (2014) menunjukan bahwa opini audit berpengaruh secara positif terhadap audit report lag karena ketika perusahaan mendapat opini selain unqualified opinion maka auditor akan mencari bukti-bukti penyebab di keluarkannya opini selain unqualified opinion. Pencarian bukti-bukti tersebut yang akan mengindikasikan terjadinya audit report lag.

Menurut Praptika dan Rasmini (2016) apabila perusahaan melakukan pergantian auditor, maka auditor yang baru membutuhkan waktu yang cukup lama untuk memahami karakteristik usaha klien dan sistem yang ada, hal ini menyita waktu auditor dalam melaksanakan proses auditnya dan dapat menyebabkan keterlambatan dalam penyampaian laporan keuangan.

Hasil penelitian yang dilakukan oleh Nufita (2017) menunjukan bahwa profitabilitas memiliki pengaruh terhadap audit report lag, karena banyak perusahaan yang memperhatikan profitabilitasnya agar terhindar dari makin panjangnya audit report lag. Profitabilitas yang baik akan segera dipublikasikan laporan keuangannya. Sebaliknya, perusahaan cenderung tidak tepat waktu dalam penyampaian laporan keuangan tahunannya jika profitabilitas perusahaan tersebut sedang mengalami penurunan.

\section{Tujuan Penelitian}

Tujuan penelitian ini adalah Menganalisis pengaruh opini audit, pergantian auditor, dan profitabilitas terhadap audit report lag secara parsial maupunbersama-sama pada perusahaan sektor perdagangan eceran yang terdaftar di Bursa Efek Indonesia periode 2011-2018.

\section{Tinjauan Pustaka}

\section{Audit Report LAG}

Lamanya waktu penyelesaian audit dapat mempengaruhi ketepatan waktu dalam penyampaian informasi berupa laporan keuangan untuk dipublikasikan 
yang berdampak pada reaksi pasar dan mempengaruhi pengambilan keputusan yang didasarkan pada laporan dipublikasikan tersebut. Menurut Widhiasari dan Budiartha (2016) Audit report lag merupakan rentang waktu penyelesaian audit dimulai dari tanggal tutup buku perusahaan sampai tanggal yang tercantum dalam laporan audit. Widhiasari dan Budiartha (2016) menggunakan tiga kriteria keterlambatan, antara lain: (1) Preliminary lag (interval jumlah hari antara tanggal laporan keuangan sampai dengan penerimaan laporan akhir preliminary oleh bursa); (2) Auditor's report lag (interval jumlah hari antara tanggal laporan keuangan sampai dengan tanggal laporan audit ditandatangani); (3)Totallag (interval jumlah hari antara tanggal laporan keuangan sampai dengan tanggal penerimaan laporan dipublikasikan di bursa).

\section{Opini Audit}

Menurut Halim (2018:73) Opini audit merupakan kesimpulan kewajaran atas informasi yang telah diaudit. Dikatakan wajar dibidang auditing apabila bebas dari keraguan-keraguan dan ketidakjujuran dan lengkap informasinya. Terdapat lima tipe opini audit yang diberikan oleh auditor yaitu pendapat wajar tanpa pengecualian, pendapat wajar tanpa pengecualian dengan bahasa penjelasan, pendapat wajar dengan pengecualian, pendapat tidak wajar, dan pernyataan tidak memberikan pendapat (Mulyadi, 2014:19-22).

\section{Pergantian Auditor}

Menurut Kurniawan (2017) Auditor switching merupakan pergantian kantor akuntan publik yang dilakukan oleh perusahaan (klien) dalam pemberian penugasan audit atas laporan keuangan. Auditor switching bisa terjadi karena ada regulasi atau peraturan yang mewajibkan perusahaan yang melakukan rotasi KAP dan juga karena keinginan dari perusahaan melakukan pergantian secara sukarela diluar peraturan yang berlaku.

\section{Profitabilitas}

Menurut Warren,et al (2015:859) analisis profitabilitas menitikberatkan pada kemampuan perusahaan untuk menghasilkan laba. Hubungan antara laporan laba rugi dan laporan posisi keuangan sering kali digunakan untuk mengevaluasi 
profitabilitas. Analisis utama untuk profitabilitas antara lain : rasio penjualan bersih terhadap aset, tingkat pengembalian terhadap total aset, tingkat pengembalian terhadap ekuitas pemegang saham, tingkat pengembalian terhadap ekuitas pemegang saham biasa, laba per saham, rasio harga terhadap laba, deviden per saham dan dividend yield.

\section{METODE PENELITIAN}

Penelitian ini bersifat kuantitatif serta memakai metode deskriptif.digunakan untuk mengidentifikasi pengaruh opini audit, pergantian auditor dan profitabilitas terhadap audit report lag pada perusahaan sub sektor perdagangan eceran yang terdaftar di Bursa Efek Indonesia periode 2011-2018. Data yang digunakan yaitu data sekunder berupa annual report. Teknik pengambilan sampel dalam penelitian ini adalah metode purposive sampling,terdapat 6 sampel perusahaan dari 26 perusahaan.Sedangkan teknik analisis data dilakukan dengan menggunakan metode analisis regresi linear berganda.

\section{Hasil Dan Pembahasan}

Tabel 1. Hasil Uji S

Descriptive Statistics

\begin{tabular}{|l|r|r|r|r|r|r|r|}
\hline & $\mathrm{N}$ & Range & Minimum & Maximum & Sum & Mean & $\begin{array}{c}\text { Std. } \\
\text { Deviation }\end{array}$ \\
\cline { 2 - 8 } & Statistic & Statistic & Statistic & Statistic & Statistic & Statistic & Statistic \\
\hline $\begin{array}{l}\text { Audit Report } \\
\text { Lag }\end{array}$ & 48 & 96 & 40 & 136 & 3602 & 75,04 & 16,986 \\
Opini Audit & 48 & 1 & 0 & 1 & 36 & 0,75 & 0,438 \\
$\begin{array}{l}\text { Pergantian } \\
\text { Auditor }\end{array}$ & 48 & 1 & 0 & 1 & 7 & 0,15 & 0,357 \\
$\begin{array}{l}\text { Profitabilitas } \\
\text { Valid N } \\
\text { (listwise) }\end{array}$ & 48 & 0,45 & 0,01 & 0,46 & 5,85 & 0,1219 & 0,12022 \\
\hline
\end{tabular}

Sumber: Hasil olah data statistik, 2019

\section{Statistik Deskriptif Audit Report Lag}

Tabel 1. diatas menjelaskan mengenai audit report lag yang berasal dari perusahaan sektor perdagangan eceran menunjukkan bahwa waktu pelaksanaan audit 
minimal yaitu 40 hari dan waktu pelaksanaan maksimum yaitu 136 hari, dengan ratarata audit report lag adalah 75,04 hari, sedangkan standar deviasi sebesar 16,98. Dapat dilihat bahwa rata-rata audit report lag perusahaan sektor perdagangan eceran yang terdaftar di Bursa Efek Indonesia periode 2011-2018 masih dibawah 120 hari kalender hal ini sesuai dengan ketetapan yang telah diatur oleh Otoritas Jasa Keuangan (OJK) mengenai penyampaian laporan keuangan tahunan perusahaan. PT. Matahari Department Store Tbk menjadi perusahaan tercepat dan terlama dalam audit report lag, tercatat pada tahun 2011 selama 136 hari dan ditahun 2012 selama 40 hari.

Tabel 2. Hasil Uji Statistik Deskriptif Opini Audit

\begin{tabular}{|l|r|r|r|r|}
\hline & & & & Opini Audit (X1) \\
& Frequency & Percent & Valid Percent & \multicolumn{1}{c|}{ Percent } \\
\hline Valid Opini Audit Selain WTP & 12 & 25,0 & 25,0 & 25,0 \\
Opini Audit WTP & 36 & 75,0 & 75,0 & 100,0 \\
Total & 48 & 100,0 & 100,0 & \\
\hline
\end{tabular}

Sumber : Hasil olah data statistik, 2019.

Berdasarkan dari hasil statistik yang diperoleh diatas (tabel 2) dapat diketahui bahwa sebesar $25 \%$ perusahaan perdagangan eceran yang terdaftar di Bursa Efek Indonesia periode 2011-2018 menerima opini selain audit wajar tanpa pengecualian, sementara perusahaan yang menerima opini wajar tanpa pengecualian sebesar 75\%. Selama periode 2011-2018 PT. Matahari Department Store Tbk tidak pernah mendapat opini audit selain wajar tanpa pengecualian. Perusahaan yang mendapat opini audit selain wajar tanpa pengecualian terbanyak yaitu PT. Mitra Adi Perkasa Tbk, diketahui tahun 2011, 2012, 2015 dan pada tahun 2017 perusahaan tersebut mendapat opini audit selain wajar tanpa pengecualian. 
Tabel 3. Hasil Uji Statistik Deskriptif Pergantian Auditor

\begin{tabular}{|l|r|r|r|r|}
\hline & Pergantian Auditor (X2) \\
\hline & Frequency & Percent & $\begin{array}{c}\text { Valid } \\
\text { Percent }\end{array}$ & \multicolumn{1}{c|}{$\begin{array}{c}\text { Cumulative } \\
\text { Percent }\end{array}$} \\
\hline $\begin{array}{l}\text { Valid Tidak Melakukan } \\
\text { Pergantian Auditor } \\
\text { Melakukan Pergantian }\end{array}$ & 41 & 85,4 & 85,4 & 85,4 \\
Auditor & 7 & 14,6 & 14,6 & 100,0 \\
Total & 48 & 100,0 & 100,0 & \\
\hline
\end{tabular}

Sumber : Hasil olah data statistik, 2019.

Pergantian auditor dalam penelitian ini menggunakan variabel dummy yang di kategorikan menjadi dua yaitu perusahaan yang melakukan pergantian auditor dan perusahaan yang tidak melakukan pergantian auditor.Berdasarkan dari hasil statistik yang diperoleh diatas dapat diketahui bahwa sebesar 85,4\% perusahaan perdagangan eceran yang terdaftar di Bursa Efek Indonesia periode 2011-2018 tidak melakukan pergantian auditor, sebesar 14,6\% perusahaan perdagangan eceran melakukan pergantian auditor. Dari 48 sampel yang diteliti, 7 perusahaan diketahui melakukan pergantian auditor, sisanya sebanyak 41 perusahaan tidak melakukan pergantian auditor. Diketahui tahun 2015 PT. Mitra Adi Perkasa Tbk telah melakukan pergantian auditor, namun di tahun 2016 PT. Mitra Adi Perkasa Tbk melakukan pergantian auditor kembali. Tercatat selama periode 2011-2018 hanya PT. Mitra Adi Perkasa Tbk yang melakukan pergantian auditor sebanyak dua kali.

Tabel 4. Hasil Uji Statistik Deskriptif Profitabilitas

\begin{tabular}{|l|r|r|r|r|r|r|r|}
\hline & $\mathrm{N}$ & Range & Minimum & Maximum & Sum & Mean & \multicolumn{1}{c|}{$\begin{array}{c}\text { Std. } \\
\text { Deviation }\end{array}$} \\
\cline { 2 - 8 } & Statistic & Statistic & Statistic & Statistic & Statistic & Statistic & \multicolumn{1}{c|}{ Statistic } \\
\hline $\begin{array}{l}\text { Audit Report } \\
\text { Lag }\end{array}$ & 48 & 96 & 40 & 136 & 3602 & 75,04 & 16,986 \\
Opini Audit & 48 & 1 & 0 & 1 & 36 & 0,75 & 0,438 \\
$\begin{array}{l}\text { Pergantian } \\
\text { Auditor }\end{array}$ & 48 & 1 & 0 & 1 & 7 & 0,15 & 0,357 \\
$\begin{array}{l}\text { Profitabilitas } \\
\text { Valid N }\end{array}$ & 48 & 0,45 & 0,01 & 0,46 & 5,85 & 0,1219 & 0,12022 \\
(listwise) & 48 & & & & & & \\
\hline
\end{tabular}

Sumber: Hasil olah data statistik, 2019 


\section{Ningsih \& Agustina}

Profitabilitas digunakan untuk menilai sejauh mana kemampuan perusahaan dalam mencari keuntungan atau laba dalam suatu periode tertentu. Tingkat profitabilitas perusahaan dalam penelitian ini diukur menggunakan indikator Return On Assets (ROA), rasio yang mengukur perbandingan antara laba setelah pajak dan total aset.Berdasarkan hasil analisis statistik deskriptif dapat diketahui bahwa profitabilitas dari perusahaan sektor perdagangan eceran yang dijadikan sampel memiliki nilai minimal 0,01 dan nilai maksimum 0,46 dengan nilai rata-ratanya 0,121 dan standar deviasi sebesar 0,120 .Terdapat tiga perusahaan perdagangan eceran yang memiliki tingkat profitabilitas terendah yaitu 0,01 diantaranya PT. Sumber Alfaria Trijaya Tbk di tahun 2017, PT. Mitra Adi Perkasa Tbk di tahun 2014 dan 2015, lalu PT. Catur Sentosa Adiprana Tbk di tahun 2015. Perusahaan yang memiliki tingkat profitabilitas tertinggi dengan nilai 0,46 yaitu PT. Matahari Department Store Tbk di tahun 2015.

\section{Hasil Uji Asumsi Klasik}

a.Uji Normalitas

Uji normalitas dalam penelitian ini menggunakan Kolmogorov-Smirnov. Dasar pengambilan keputusan dalam uji Kolmogorov-Smirnov adalah apabila nilai signifikansi (sig) > 0,05 atau 5\% maka data berdistribusi normal, sebaliknya apabila nilai signifikansi (sig) $<0,05$ maka tidak berdistribusi normal (Ghozali, 2013:160).

Tabel 5. Hasil Uji Normalitas K-S

\begin{tabular}{|ll|r|}
\hline \multicolumn{2}{|c|}{ One-Sample Kolmogorov-Smirnov Test } \\
\hline N & & $\begin{array}{c}\text { Unstandardized } \\
\text { Residual }\end{array}$ \\
Normal Parameters ${ }^{\mathrm{a}, \mathrm{b}}$ & Mean & 48 \\
& Std. &, 0000000 \\
& Deviation & 15,00856810 \\
Most Extreme & Absolute &, 115 \\
Differences & Positive &, 115 \\
& Negative &,- 073 \\
Test Statistic & &, 115 \\
Asymp. Sig. (2-tailed) & &, $129^{\mathrm{c}}$ \\
\hline
\end{tabular}

a. Test distribution is Normal.

Sumber: Data diolah, 2019 
Vol. 3 No.1, Desember 2019, 68 - 87

\section{Ningsih \& Agustina}

Berdasarkan hasil pengujian diatas, menunjukan bahwa koefisien Asymp. Sig. (2-tailed) dalam penelitian ini sebesar 0,129 yang berarti nilai signifikansi > 0,05. Maka dapat disimpulkan bahwa nilai residual terdistribusi secara normal dan model penelitian memenuhi kriteria asumsi normalitas.

\section{b. Uji Linearitas}

Menurut Sugiyono (2016:159) Tujuan uji linearitas adalah untuk mengetahui hubungan antara variabel bebas dan variabel terikat linear atau tidak.

\section{Tabel 6.Uji Linearitas Variabel Opini Audit}

\begin{tabular}{|c|c|c|c|c|c|c|c|}
\hline \multicolumn{8}{|c|}{ ANOVA Table } \\
\hline & & & $\begin{array}{l}\text { Sum of } \\
\text { Squares }\end{array}$ & $d f$ & $\begin{array}{l}\text { Mean } \\
\text { Square }\end{array}$ & $\mathrm{F}$ & Sig. \\
\hline \multirow{5}{*}{$\begin{array}{l}\text { Audit Report Lag * } \\
\text { Opini Audit }\end{array}$} & Between & (Combined) & 921,377 & 4 & 230,344 & ,890 & ,478 \\
\hline & Groups & Linearity & 225,431 & 1 & 225,431 & ,871 & ,356 \\
\hline & & $\begin{array}{l}\text { Deviation from } \\
\text { Linearity }\end{array}$ & 695,946 & 3 & 231,982 & ,897 & ,451 \\
\hline & \multicolumn{2}{|c|}{ Within Groups } & 11126,744 & 43 & 258,761 & & \\
\hline & \multicolumn{2}{|l|}{ Total } & 12048,121 & 47 & & & \\
\hline
\end{tabular}

Sumber: Data diolah, 2019

Tabel 7. Uji Linearitas Variabel Pergantian Auditor

\begin{tabular}{|c|c|c|c|c|c|c|c|}
\hline \multicolumn{8}{|c|}{ ANOVA Table } \\
\hline & & & $\begin{array}{l}\text { Sum of } \\
\text { Squares }\end{array}$ & Df & $\begin{array}{l}\text { Mean } \\
\text { Square }\end{array}$ & $\mathrm{F}$ & Sig. \\
\hline \multirow{5}{*}{$\begin{array}{l}\text { Audit Report Lag * } \\
\text { Pergantian Auditor }\end{array}$} & Between & (Combined) & 324,742 & 3 & 108,247 & ,406 & ,749 \\
\hline & Groups & Linearity & ,815 & 1 & ,815 & ,003 & ,956 \\
\hline & & $\begin{array}{l}\text { Deviation from } \\
\text { Linearity }\end{array}$ & 323,927 & 2 & 161,964 & ,608 &, 549 \\
\hline & \multicolumn{2}{|c|}{ Within Groups } & 11723,378 & 44 & 266,440 & & \\
\hline & \multicolumn{2}{|l|}{ Total } & 12048,121 & 47 & & & \\
\hline
\end{tabular}


Tabel 8. Uji Linearitas Variabel Profitabilitas

\begin{tabular}{|c|c|c|c|c|c|c|c|}
\hline \multicolumn{8}{|c|}{ ANOVA Table } \\
\hline & & & $\begin{array}{l}\text { Sum of } \\
\text { Squares }\end{array}$ & df & $\begin{array}{l}\text { Mean } \\
\text { Square }\end{array}$ & $\mathrm{F}$ & Sig. \\
\hline \multirow{5}{*}{$\begin{array}{l}\text { Audit Report Lag * } \\
\text { Profitabilitas }\end{array}$} & Between & (Combined) & 11006,539 & 39 & 282,219 & 2,168 & ,124 \\
\hline & Groups & Linearity & 2019,573 & 1 & 2019,573 & 15,512 & ,004 \\
\hline & & $\begin{array}{l}\text { Deviation from } \\
\text { Linearity }\end{array}$ & 8986,966 & 38 & 236,499 & 1,816 & 189 \\
\hline & \multicolumn{2}{|c|}{ Within Groups } & 1041,582 & 8 & 130,198 & & \\
\hline & \multicolumn{2}{|l|}{ Total } & 12048,121 & 47 & & & \\
\hline
\end{tabular}

Hasil uji linearitas pada tabel 6,7,8 dibawah ini menunjukan bahwa semua variabel bebas memiliki nilai signifikansi yang lebih besar dari 0,05. Dapat dilihat pada variabel opini audit Deviation from linearity menunjukan nilai signifikansi 0,451, variabel pergantian auditor Deviation from linearity menunjukan nilai signifikansi 0,549, dan variabel profitabilitas Deviation from linearity menunjukan nilai signifikansi 0,189 .

\section{c. Uji Multikolinearitas}

Uji multikolineritas menguji apakah dalam model regresi ditemukan adanya korelasi antara variabel bebas. Model regresi yang baik menunjukkan tidak terjadi korelasi antara variabel independen.

Tabel 9. Hasil Uji Multikolinearitas

\begin{tabular}{|c|c|c|c|c|}
\hline & Coefficients & & & \\
\hline \multirow{2}{*}{ Model } & \multicolumn{2}{|c|}{ Unstandardized Coefficients } & \multicolumn{2}{|c|}{ Collinearity Statistics } \\
\hline & $B$ & Std. Error & Tolerance & VIF \\
\hline (Constant) & 85,228 & 4,917 & & \\
\hline Opini Audit & $-2,785$ & 5,239 & 0,974 & 1,027 \\
\hline 1 Pergantian Auditor & $-2,282$ & 6,35 & 0,998 & 1,002 \\
\hline Profitabilitas & $-63,706$ & 19,071 & 0,974 & 1,027 \\
\hline
\end{tabular}

a. Dependent Variable: Audit Report Lag

Sumber: Data diolah, 2019 
Berdasarkan tabel diatas menunjukan bahwa semua variabel bebas memiliki nilai tolerance $>0,10 \& \mathrm{VIF}<10$. Sehingga dari hasil uji tersebut dapat disimpulkan bahwa dalam model regresi tidak terjadi masalah multikolinearitas.

\section{d. Uji Autokorelasi}

Uji autokorelasi bertujuan untuk menguji apakah dalam model regresi linier ada korelasi antara kesalahan pengganggu pada periode t dengan kesalahan pengganggu pada periode t-1 (sebelumnya). Pengujian autokorelasi dalam penelitian ini menggunakan Durbin Watson (DW-Test).

Tabel 10. Hasil Uji Autokorelasi

\begin{tabular}{|l|c|r|r|r|r|}
\hline Model & $\mathrm{R}$ & R Square & Adjusted R Square & Std. Error of the Estimate & Durbin-Watson \\
\hline 1 &, $416^{\mathrm{a}}$ &, 173 &, 117 & 15,04422 & 2,055 \\
\hline
\end{tabular}

Sumber: Data diolah, 2019

Berdasarkan hasil pengujian Durbin Watson pada tabel 10, diperoleh nilai $\mathrm{DW}=2,055$. Berdasarkan jumlah data sebanyak $48(\mathrm{n}=48)$ serta 3 variabel independen $(\mathrm{k}=3)$ pada tingkat signifikansi 5\%, diperoleh nilai $\mathrm{dL}=1,406$ dan $\mathrm{dU}=1,670$. Nilai batas atas $\mathrm{dU}(1,670)<\mathrm{DW}(2,055)<$ dari 4 -dU $(4-1,670)=$ 2,33. Dapat disimpulkan bahwa tidak terdapat autokorelasi dalam model regresi yang digunakan dalam penelitian ini.

\section{e. Uji Heteroskedastisitas}

Uji heteroskedastisitas bertujuan untuk menguji apakah dalam suatu model regresi terjadi ketidaksamaan varians dari residual satu ke pengamatan yang lain. Untuk mengetahui ada atau tidaknya heteroskedastisitas ditandai dengan tidak adanya satupun variabel independen yang dapat mempengaruhi variabel absolut residual. Pengujian dalam penelitian ini menggunakan uji Glejser. Hasil uji heteroskedastisitas dengan Glejser dapat dilihat pada tabel berikut: 
Tabel 11. Hasil Uji Heteroskedastisitas dengan Glejser

\begin{tabular}{|c|r|r|r|r|r|}
\hline \multirow{2}{*}{ Model } & \multicolumn{2}{|c|}{$\begin{array}{c}\text { Unstandardized } \\
\text { Coefficients }\end{array}$} & $\begin{array}{c}\text { Standardized } \\
\text { Coefficients }\end{array}$ & \multirow{2}{*}{ T } & Sig. \\
\cline { 2 - 4 } & B & $\begin{array}{c}\text { Std. } \\
\text { Error }\end{array}$ & Beta & & \\
\hline \multirow{2}{*}{ (Constant) } & 6,505 & 3,491 & & 1,863 & 0,069 \\
Opini Audit & 1,807 & 3,72 & 0,072 & 0,486 & 0,63 \\
1 Pergantian & $-0,639$ & 4,509 & $-0,021$ & $-0,142$ & 0,888 \\
Auditor & 19,434 & 13,542 & 0,213 & 1,435 & 0,158 \\
\hline
\end{tabular}

a. Dependent Variable:RES_2

Sumber: Data diolah, 2019

Berdasarkan hasil uji heteroskedastisitas dengan menggunakan Glejser, dapat disimpulkan bahwa masing-masing variabel opini audit, pergantian auditor, dan profitabilitas memiliki nilai signifikansi $>0,05$. Sehingga dapat disimpulkan bahwa dalam model regresi dalam penelitian ini tidak terjadi heteroskedastisitas.

\section{Hasil Uji Hipotesis}

\section{a. Analisis Regresi Linear Berganda}

Penelitian ini menggunakan teknik regresi linear berganda (multiple regression). Menurut Sugiyono (2017:275) analisis regresi linear berganda akan dilakukan bila jumlah variabel independennya minimal dua.

Tabel 12. Hasil Uji Regresi Berganda

\begin{tabular}{|c|c|c|c|c|c|}
\hline \multirow[b]{3}{*}{ Model } & \multicolumn{3}{|c|}{ Coefficients $^{a}$} & \multirow[b]{3}{*}{$\mathrm{T}$} & \multirow[b]{3}{*}{ Sig. } \\
\hline & \multicolumn{2}{|c|}{$\begin{array}{c}\text { Unstandardized } \\
\text { Coefficients }\end{array}$} & $\begin{array}{l}\text { Standardized } \\
\text { Coefficients }\end{array}$ & & \\
\hline & $\mathrm{B}$ & Std. Error & Beta & & \\
\hline 1 (Constant) & 64,310 & 3,962 & & 16,232 &, 000 \\
\hline Opini Audit & $-2,688$ & 4,942 &,- 076 &,- 544 & ,589 \\
\hline Pergantian Auditor &,- 962 & 5,983 &,- 022 &,- 161 & ,873 \\
\hline Profitabiltas & $-66,843$ & 23,319 &,- 398 & $-2,866$ &, 006 \\
\hline
\end{tabular}

a. Dependent Variable: Audit Report Lag

Sumber: Data diolah, 2019.

Berdasarkan hasil pengujian regresi diatas, maka dapat dibuat suatu model regresi linear berganda dengan persamaan sebagai berikut: 


$$
\text { ARLag }=64,310-2,688 \text { OA }-0,962 \text { PAU }-66,843 \text { PRO }
$$

Dari hasil model persamaan regresi diatas, maka kesimpulan yang dapat diambil dalam penelitian ini adalah sebagai berikut:

1. Nilai intercept konstanta sebesar 64,310. Hasil tersebut dapat diartikan, apabila besarnya nilai seluruh variabel independen yaitu opini audit, pergantian auditor, dan profitabilitas adalah 0, maka besarnya nilai audit report lagakan sebesar 64,310.

2. Nilai koefisien regresi variabel opini audit adalah sebesar -2,688. Hasil tersebut dapat diartikan bahwa apabila variabel opini audit naik satu satuan, maka audit report lag akan mengalami penurunan sebesar 2,688 satuan atau hari, dengan asumsi bahwa semua variabel independen lain adalah konstan.

3. Nilai koefisien regresi variabel pergantian auditor adalah sebesar -0,962. Hasil tersebut dapat diartikan bahwa apabila variabel pergantian auditor naik satu satuan, maka audit report lagakan mengalami penurunan sebesar 0,962 satuan atau hari.

4. Nilai koefisien regresi variabel profitabilitas adalah sebesar $-66,843$. Hasil tersebut dapat diartikan bahwa apabila variabel profitabilitas naik satu satuan, maka audit report lagakan mengalami penurunan sebesar 66,843 satuan atau hari.

\section{b. Uji Secara Parsial (Uji t)}

Uji-t menunjukan seberapa jauh pengaruh satu variabel independen secara individual (parsial) dalam menerangkan variabel dependen (Ghozali, 2013:98).

Tabel 13. Hasil Uji Parsial (Uji t)

\begin{tabular}{|l|r|r|r|r|r|}
\hline \multirow{2}{*}{ Model } & \multicolumn{2}{|c|}{$\begin{array}{c}\text { Unstandardized } \\
\text { Coefficients }\end{array}$} & $\begin{array}{c}\text { Standardized } \\
\text { Coefficients }\end{array}$ & & \\
\cline { 2 - 5 } & \multicolumn{1}{|c|}{$\mathrm{B}$} & Std. Error & Beta & $\mathrm{T}$ & Sig. \\
\hline 1 (Constant) & 64,310 & 3,962 & & 16,232 &, 000 \\
Opini Audit & $-2,688$ & 4,942 &,- 076 &,- 544 &, 589 \\
Pergantian Auditor &,- 962 & 5,983 &,- 022 &,- 161 &, 873 \\
Profitabiltas & $-66,843$ & 23,319 &,- 398 & $-2,866$ &, 006 \\
\hline
\end{tabular}

Dependent Variable: Audit Report Lag

Sumber: Data diolah, 2019. 
Berdasarkan hasil pengujian hipotesis parsial (Uji t) diatas, maka kesimpulan yang dapat diambil adalah sebagai berikut:

1. Pengujian Hipotesis Pertama

Hasil pengujian hipotesis pertama menunjukan bahwa nilai $\mathrm{t}$ hitung sebesar $-0,544$ dan nilai $\mathrm{t}$-tabel $\mathrm{df}=45$ pada tingkat signifikansi $\alpha=5 \%$ sebesar 2,014, dimana nilai t-hitung lebih kecil dari t-tabel $(-0,544<2,014)$. Hal tersebut juga didukung dengan hasil nilai signifikansi 0,58 lebih besar dari 0,05 (0,58 > 0,05). Sehingga disimpulkan $\mathrm{H}_{1}$ ditolak dan $\mathrm{H}_{01}$ diterima maka hipotesisnya adalah $\mathrm{H}_{0}: \beta_{1}=0$. Artinya bahwa secara parsial tidak terdapat pengaruh antara variabel opini audit terhadap audit report lag.

Diketahui bahwa nilai koefisien regresi opini audit sebesar -2,688 bernilai negatif, yang berati apabila perusahaan mendapat opini wajar tanpa pengecualian akan memiliki audit report lag yang lebih pendek dan perusahaan yang mendapat opini selain wajar tanpa pengecualian maka audit report lag akan semakin panjang.Penelitian ini bertolak belakang dengan penelitian yang telah dilakukan oleh Lusiana dan Rahma (2017) yang berkesimpulan bahwa opini audit berpengaruh signifikan terhadap audit report lag

Hasil penelitian ini juga didukung dengan fakta bahwa PT Mitra Adiperkasa Tbk pada tahun 2017 mendapatkan opini audit selain wajar tanpa pengecualian dan tidak mengalami keterlambatan publikasi laporan keuangan, laporan publikasi PT Mitra Adiperkasa Tbk pada tahun 2017 tersebut diterbitkan setelah 87 hari dari tanggal tutup buku. Sedangkan pada tahun 2011 PT Matahari Department Store Tbk mendapatkan opini audit wajar tanpa pengecualian dan mengalami audit report lag selama 136 hari. Dengan demikian dapat diartikan bahwa opini audit tidak berpengaruh terhadap audit report lag pada perusahaan perdagangan eceran yang terdaftar di Bursa Efek Indonesia (BEI) periode 20112018.

2. Pengujian Hipotesis Kedua

Hasil pengujian hipotesis kedua menunjukan bahwa nilai t hitung sebesar 0,161 dengan nilai t-tabel $\mathrm{df}=45$ pada tingkat signifikansi $\alpha=5 \%$ sebesar 2,014. Hal tersebut juga didukung dengan hasil nilai signifikansi 0,87 lebih besar dari $0,05(0,87>0,05)$. Sehingga disimpulkan bahwa $\mathrm{H}_{2}$ ditolak dan $\mathrm{H}_{02}$ diterima maka 
hipotesisnya adalah $\mathrm{H}_{0}: \beta_{2}=0$. Artinya secara parsial tidak terdapat pengaruh antara variabel pergantian auditor terhadap audit report lag.

Diketahui bahwa nilai koefisien regresi pergantian auditor sebesar -0,962 bernilai negatif, yang berati apabila perusahaan mendapat opini wajar tanpa pengecualian akan memiliki audit report lag yang lebih pendek dan perusahaan yang mendapat opini selain wajar tanpa pengecualian maka audit report lag akan semakin panjang.

Hasil penelitian ini sesuai dengen penelitian yang telah dilakukan oleh Widhiasari dan Budiartha (2016), yang mengindikasikan bahwa perusahaan yang melakukan pergantian auditor tidak berpengaruh terhadap audit report lag. Berbeda dengan hasil penelitian yang telah dilakukan oleh Praptika dan Rasmini (2016) yang menyebutkan bahwa pergantianauditor berpengaruh positif terhadap audit report lag. Pergantian auditor tidak menjamin ketepatan waktu penyampaian laporan keuangan perusahaan. Lamanya proses audit tidak dipengaruhi oleh pergantian auditor, hal ini dikarenakan pergantian auditor bisa dilakukan jauh sebelum tahun tutup buku berakhir. Dalam banyak kasus, keputusan untuk menerima klien dibuat dalam jangka waktu enam hingga sembilan bulan sebelum tahun fiskal klien berakhir (Tambunan, 2014). Sehingga auditor yang baru dapat melakukan perencanaan audit untuk memahami ruang lingkup bisnis klien dan risiko audit klien dari awal sehingga tidak mempengaruhi proses audit.

Hasil penelitian ini juga didukung dengan fakta bahwa PT Sumber Alfaria Trijaya Tbk diketahui melakukan pergantian auditor di tahun 2015 dan laporan keuangan yang telah diaudit dipublikasikan selama 70 hari sejak tanggal tutup buku dan tidak mengalami audit report lag yang panjang. Sedangkan PT Catur Sentosa Adiprana Tbk pada tahun 2018 tidak melakukan pergantian auditor akan tetapi mengalami audit report lag selama 87 hari, lebih besar dibandingkan PT Sumber Alfaria Trijaya Tbk tahun 2015 yang melakukan pergantian auditor. Dengan demikian, dapat disimpulkan bahwa tidak terdapat pengaruh antara pergantian auditor dengan audit report lag pada perusahaan perdagangan eceran yang terdaftar di Bursa Efek Indonesia (BEI) periode 2011-2018. 


\section{Pengujian Hipotesis Ketiga}

Hipotesis ketiga dalam penelitian ini adalah profitabilitas berpengaruh negatif dan signifikan terhadap audit report lag. Berdasarkan hasil regresi yang ditunjukan pada tabel diatas, dapat dilihat bahwa nilai koefisien regresi profitabilitas sebesar $-66,843$ dan memiliki nilai negatif, menunjukan bahwa setiap adanya perubahan 1 satuan tingkat profitabilitas, maka dapat menurunkan variabel audit report lag sebesar 66,843.

Uji t statistic variable opini audit menunjukan bahwa t-hitung sebesar 2,866 dengan nilai t-tabel $\mathrm{df}=45$ pada tingkat signifikansi $\alpha=5 \%$ sebesar 2,014. Apabila keduanya dibandingkan maka koefisien variable regresi tersebut signifikan, dimana nilai t-hitung lebih besar dari t-tabel $(-0,161>2,014)$. Hal tersebut juga didukung dengan hasil nilai signifikansi 0,006 lebih kecil dari 0,05 $(0,006<0,05)$. Sehingga dapat disimpulkan bahwa terdapat pengaruh signifikan antara variabel profitabilitas dengan audit report lag. Berdasarkan hasil pengujian tersebut maka $\mathrm{H}_{3}$ diterima dan $\mathrm{H}_{0}$ ditolak, yang artinya bahwa secara parsial terdapat pengaruh negatif signifikan antara variable profitabilitas terhadap audit report lag.Sehingga disimpulkan bahwa $\mathrm{H}_{3}$ diterima dan $\mathrm{H}_{03}$ ditolak, maka hipotesisnya adalah $\mathrm{H}_{3}: \beta_{3} \neq 0$.Artinya secara parsial terdapat pengaruh yang signifikan antara variabel profitabilitas terhadap audit report lag.

Hasil penelitian ini sesuai dengan penelitian yang telah dilakukan olehSuparsada dan Putri (2017) yang menunjukan bahwa profitabilitas berpengaruh negatif signifikan terhadap audit report lag. Kemampuan perusahaan untuk menghasilkan laba berdasarkan aktiva yang dimiliki mempunyai pengaruh secara signifikan terhadap jangka waktu penyampaian laporan keuangan auditan. Banyak perusahaan yang mengalami kenaikan profit yang menyebabkan publikasi semakin cepat. Selain itu diindikasikan tuntutan pihak-pihak yang berkepentingan seperti investor dan kreditor cukup tinggi sehingga memacu perusahaan untuk mengkomunikasikan laporan keuangan yang diaudit lebih cepat.

Hasil penelitian juga didukung dengan data yang menunjukan bahwa PT Matahari Department Store Tbk tahun 2015 memiliki nilai profitabilitas tertinggi dan mengalami audit report lag selama 46 hari. Sedangkan PT Sumber Alfaria Trijaya Tbk tahun 2017 memiliki nilai profitabilitas terendah dan mengalami 
audit report lag yang lebih panjang yaitu selama 75 hari. Dengan demikian dapat diartikan bahwa semakin tinggi nilai profitabilitas perusahaan, maka semakin pendek audit report lag yang dialami oleh perusahaan tersebut. Dapat disimpulkan bahwa terdapat pengaruh negatif signifikan antara profitabilitas dengan audit report lag pada perusahaan perdagangan eceran yang terdaftar di Bursa Efek Indonesia (BEI) periode 2011-2018.

\section{c. Uji Secara Simultan (Uji F)}

Uji statistik atau uji simultan, bertujuan untuk menguji apakah semua variabel independen atau variabel bebas yang dimasukkan ke dalam model regresi mempunyai pengaruh secara bersama-sama (simultan) terhadap variabel dependen atau variabel terikatnya. Pengujian dilakukan dengan membandingkan antara F hitung dengan F tabel. Dasar pengambilan keputusan yaitu jika tingkat signifikansi $\mathrm{F}<0,05$ maka hipotesis diterima, artinya semua variable independen secara bersama sama berpengaruh terhadap variable dependen. Hasil pengujian uji F statistic adalah sebagai berikut:

Tabel 14. Hasil Uji Simultan (Uji F)

\begin{tabular}{|l|l|l|l|l|l|}
\hline \multicolumn{1}{|c|}{ ANOVA $^{\mathrm{a}}$} \\
\hline 1 Rodel & Sum of Squares & df & Mean Square & F & Sig. \\
\hline Residual & 9958,458 & 44 & 226,329 & & \\
Total & 12048,121 & 47 & & & \\
\hline
\end{tabular}

Dependent Variable: Audit Report Lag

Sumber: Data diolah, 2019.

Hasil pengujian hipotesis keempat menunjukan bahwa nilai $f$ hitung sebesar 3,078 dengan nilai f-tabel $\mathrm{df}=44$ pada tingkat signifikansi $\alpha=5 \%$ sebesar 2,82. Hal tersebut juga didukung dengan hasil nilai signifikansi 0,037 lebih kecil dari $0,05(0,037<0,05)$. Sehingga disimpulkan bahwa $\mathrm{H}_{4}$ diterima dan $\mathrm{H}_{04}$ ditolak, maka hipotesisnya adalah $\mathrm{H}_{4}: \beta_{4} \neq 0$.Artinya secara simultan terdapat pengaruh yang signifikan antara opini audit, pergantian auditor, dan profitabilitas terhadap audit report lag. 


\section{d. Uji Koefisien Determinasi $\left(\mathbf{R}^{2}\right)$}

Uji $\mathrm{R}^{2}$ bertujuan untuk mengukur seberapa jauh kemampuan variabel independen dalam menerangkan variasi variabel dependen. Nilai koefisien determinasi adalah antara 0 dan 1 , dimana semakin tinggi nilai $\mathrm{R}^{2}$ semakin mendekati 1, maka hasil regresi tersebut semakin baik (Ghozali, 2013: 97). Hasil analisis koefisien determinasi $\left(\mathrm{R}^{2}\right)$ adalah sebagai berikut:

Tabel 15. Hasil Uji Koefisien Determinasi

Model Summary ${ }^{\mathrm{b}}$

\begin{tabular}{|c|c|c|c|c|c|}
\hline Model & $\mathrm{R}$ & $\begin{array}{c}\mathrm{R} \\
\text { Square }\end{array}$ & Adjusted R Square & $\begin{array}{c}\text { Std. Error of the } \\
\text { Estimate }\end{array}$ & $\begin{array}{c}\text { Durbin- } \\
\text { Watson }\end{array}$ \\
\hline 1 &, $416^{\mathrm{a}}$ &, 173 &, 117 & 15,04422 & 2,055 \\
\hline
\end{tabular}

Sumber: Data diolah, 2019

Dari hasil uji koefisien determinasi pada tabel 15 dapat diketahui bahwa nilai Adjusted R Square adalah 0,117. Dari hasil tersebut dapat disimpulkan bahwa seluruh variabel independen yaitu opini audit, pergantian auditor dan profitabilitas dapat mempengaruhi audit report lag pada perusahaan perdagangan eceran sebesar $11,7 \%$, sedangkan sisanya $88,3 \%$ audit report lag pada perusahaan perdagangan eceran dipengaruhi oleh faktor-faktor lain diluar penelitian.

\section{Kesimpulan}

1. Opini audit tidak berpengaruh secara parsial terhadap audit report lag pada perusahaan perdagangan eceran yang terdaftar di Bursa Efek Indonesia pada tahun 2011-2018.

2. Pergantian Auditor tidak berpengaruh secara parsial terhadap audit report lag pada perusahaan perdagangan eceran yang terdaftar di Bursa Efek Indonesia pada tahun 2011-2018.

3. Profitabilitas berpengaruh negatif signifikan secara parsial terhadap audit report lag pada perusahaan perdagangan eceran yang terdaftar di Bursa Efek Indonesia pada tahun 2011-2018.

4. Opini audit, pergantian auditor, dan profitabilitas berpengaruh signifikan secara bersama samaterhadap audit report lag pada perusahaan perdagangan eceran yang terdaftar di Bursa Efek Indonesia pada tahun 2011-2018. 


\section{DAFTAR PUSTAKA}

Ariyani, Ni Nyoman Trisna Dewi dan I Ketut Budiartha. 2014. Pengaruh Profitabilitas, Ukuran Perusahaan, Kompleksitas Operasi Perusahaan dan Reputasi KAP Terhadap Audit Report Lag Pada Perusahaan Manufaktur. EJurnal Akuntansi Universitas Udayana, hlm. 217-230.

Ghozali, Imam 2013. Aplikasi Analisis Multivariat dengan program SPSS 21 Update PLS Regresi. Edisi 7. Semarang : Badan Penerbit Universitas Diponegoro.

Halim, Abdul. 2018. Auditing, Dasar-Dasar Audit Laporan Keuangan. Jakarta: Rajawali Pers. Jilid 1. Edisi Revisi.

Ikatan Akuntansi Indonesia. 2018. SAK :Standar Akuntansi Keuangan, Jakarta: Ikatan Akuntansi Indonesia.

Kurniawan,D.2017.KarakteristikAuditeedanPerusahaanAuditSebagaiPenentuOpi ni AuditQualified(StudiEmpirispadaPerusahaanManufakturyangTerdaftardi Bursa Efek Indonesia. Skripsi Fakultas Ekonomi Universitas Diponegoro, Semarang.

Lusiana, Anita Ade Rahma. 2017. Pengaruh Firm Size, Profitability, Audit Committee Size, dan Auditor Opinion Terhadap Audit Delay Pada Perusahaan LQ-45 yang Terdaftar di Bursa Efek Indonesia Tahun 20112015. Majalah Ilmiah LPPM UPI YPTK Padang, Vol. 24, No. 1, April 2017.

Mulyadi. 2014. Auditing. Edisi Keenam. Jakarta: Salemba Empat.

Nufita, Isti. 2017. Faktor-Faktor yang Mempengaruhi Audit Report Lag. Jurnal Profita Universitas Negeri Yogyakarta, Edisi 4.

Otoritas Jasa Keuangan. 2016. Website: www.ojk.go.id

Peraturan Pemerintah Republik Indonesia No.20/2015 Tentang Praktik Akuntan Publik.

Praptika, Putu Yulia dan Ni Ketut Rasmini. 2016. Pengaruh Audit Tenure, Pergantian Auditor dan Financial Distress Pasa Audit Delay Pada Perusahaan Consumer Goods. E-Jurnal Akuntansi Universitas Udayana, Vol.10, hlm. 2052-2081.

Priyani, Mega Ghea. 2018. Audit Delay, Audit Fee, Financial Distress, Dan Opini Audit Terhadap Pergantian Auditor (Studi Empiris Pada Perusahaan Sektor Perdagangan Yang Terdaftar Di Bursa Efek Indonesia Periode 2013-2017). Skripsi. Jakarta: Sekolah Tinggi Ilmu Ekonomi Ahmad Dahlan.

Sugiyono. 2017. Metode Penelitian Kuantitatif kualitatif R\&D. Bandung: Alfabeta. 
Suparsada, Ni Putu dan IGAM Asri Dwija Putri. 2017. Pengaruh Profitabilitas, Reputasi Auditor, Ukuran Perusahaan, dan Kepemilikan Institusional Terhadap Audit Delay Pada Perusahaan Manufaktur. E-Jurnal Akuntansi Universitas Udayana, Vol.18, hlm. 60-87.

Warren carl S, James M. Reeve, Jonathan E.Duchac, Novrys Suhardianto, Devy Sulistyo Kalanjati, Amir Abadi Jusuf, Chaerul D. Djakman. 2015. Penagantar Akuntansi: Adapasi Indonesia.salemba empat ,edisi.25.

Widhiasari, Ni Made Sinta dan I Ketut Budiartha. 2016. Pengaruh Umur Perusahaan, Ukuran Perusahaan, Reputasi Auditor, dan Pergantian Auditor Terhadap Audit Report Lag. E-Jurnal Akuntansi Universitas Udayana, Vol.15, hlm. 200-227.

Widosari, Sinta Altia. 2012. Analisis Faktor-Faktor yang Berpengaruh Terhadap Audit Delay pada Perusahaan Manufaktur di Bursa Efek Indonesia Tahun 2008-2010. Skripsi. Universitas Diponegoro.

$\underline{\text { www.cnnindonesia.com Di akses April } 2019}$

$\underline{\text { www.kontan.co.id Di akses May } 2019}$ 